\title{
Experimental Organism Malignant Neuroendocrine Cell Tumor
}

National Cancer Institute

\section{Source}

National Cancer Institute. Experimental Organism Malignant Neuroendocrine Cell Tumor.

NCl Thesaurus. Code C126087.

A malignant neoplasm arising from neuroendocrine cells with evidence of invasion. 